\title{
STRATEGI PENJUALAN PEDAGANG PASAR MODERN BERBASIS CUSTOMER DATA MINING
}

\author{
Hastuti Naibaho $^{1}$, Yohanes Totok Suyoto ${ }^{2}$, Dion Dewa Barata ${ }^{3}$ \\ ${ }^{1,2,3}$ Management Study Program - Universitas Pembangunan Jaya \\ Email: hastuti.naibaho@upj.ac.id
}

\begin{abstract}
Business competition between merchant in the modern market which is is getting tighter needs effective marketing strategies. An effective sales strategy can be arranged based on the knowledge of consumers. The increasingly competitive business environment that causes businesses must continue to provide the best service to customers for the development and success of trading businesses in the present and who will date. This problem can be addressed properly if you have accurate information about customers. Accurate information about these consumers can be obtained through customer data collection methods that is called customer data mining. Customer data mining is a method of finding consumer data which includes various kinds of aspects ranging from characteristics to the way consumers purchase. Using the instrument questionnaire, this research is a consumer survey. This paper is a brief report on the results of consumer data excavation, analysis of the results of statistical data based on the results of consumer data processing, and formulation of recommendations regarding promotion and sales strategies for merchant in the modern market
\end{abstract}

Keywords: Customer Data Mining, Bundling Product, Sales Strategy

\begin{abstract}
Abstrak. Persaingan bisnis antar pedagang yang semakin ketat menuntut pedagang manciptakan strategi penjualan yang efektif. Strategi penjualan yang efektif dapat disusun berdasarkan pengetahuan tetang perilaku konsumen. Lingkungan bisnis yang semakin kompetitif menyebabkan pelaku usaha harus terus berupaya memberikan pelayanan terbaik kepada konsumen demi perkembangan dan kelangsungan usaha dagang di masa sekarang dan yang akan dating. Masalah ini dapat diatasi dengan baik jika pedagang mempunyai informasi akurat mengenai perilaku konsumen. Informasi akurat mengenai perilaku konsumen tersebut dapat diperoleh melalui metode pengalian data konsumen (customer data mining). Customer data mining merupakan metode mencari data konsumen yang mencakup berbagai macam aspek mulai dari karakteristik sampai dengan perilaku pembelian yang dilakukan konsumen. Menggunakan instrumen kuesioner, penelitian ini merupakan seuatu survei konsumen. Tulisan ini merupakan merupakan laporan singkat mengenai hasil penggalian data konsumen, analisis hasil data statistik berdasarkan hasil pengolahan data konsumen, dan rumusan rekomendasi mengenai strategi promosi dan penjualan bagi pedagang pasar modern.
\end{abstract}

Kata Kunci: Customer Data Mining, Bundling Product, Strategi Penjualan

\section{PENDAHULUAN}

Lingkungan bisnis yang semakin kompetitif menyebabkan pelaku usaha harus terus berupaya memberikan pelayanan terbaik kepada konsumen demi perkembangan dan kelangsungan usaha di masa sekarang dan yang akan datang. Tuntutan pelayanan terbaik semacam itu khususnya terjadi pada jenis usaha yang tidak pertama-tama menjalankan proses produksi tetapi hanya melakukan penjualan produk yang sudah jadi, misalnya usaha ritel. Jenis usaha ritel seringkali menghadapi masalah konsumen yang tidak loyal. Temuan survei yang dilakukan Marketing.co.id menunukkan bahwa semakin banyaknya jumlah ritel di Indonesia dan semakin dipermudahnya ijin ritel asing berdampak pada tingginya persaingan bisnis diantara sesama ritel dan ketatnya persaingan itu membuat kosumen memperoleh kemudahan untuk memilih ritel sesuai dengan kebutuhan sehingga perilaku-berpindah (switching behavior) konsumen ritel menjadi tantangan terbesar yang harus diatasi oleh pengusaha ritel di Indonesia (https://marketing.co.id/brand-switchinganalysis-dalam-industri-ritel-modern, di akses pada tanggal 16 Juli 2018).

Persaingan bisnis yang semakin ketat menuntut pelaku bisnis untuk mempunyai nilai yang lebih tinggi daripada pesaing. Bisnis ritel yang tidak melakukan proses produksi hanya dapat mengupayakan nilai-lebih tersebut melalui kualitas layanan yang diberikan kepada konsumen. Kualitas layanan itu akan mampu memungkinkan konsumen memperoleh kepuasan. Bagi bisnis ritel, kepuasan konsumen menjadi salah satu kunci keberhasilan usaha dan untuk mewujudkan terciptanya kepuasan itu, perusahaan harus dapat memahami perilaku 
konsumen mereka serta mengidentifikasi faktorfaktor yang mampu memuaskan konsumen (Griva et al., 2018). Dengan pemahaman itu, perusahaan dapat menemukan cara tepat untuk mempertahankan konsumen yang sudah ada dan bahkan menarik konsumen yang baru.

Perusahaan membutuhkan informasi yang akurat tentang konsumen terutama berkaitan dengan perilaku pembelian produk yang ditawarkan pengusaha ritel. Informasi tentang konsumen itu akan membantu perusahaan bukan hanya akan membuat perusahaan memahami perilaku konsumen dengan tepat melainkan juga meningkatkan hubungan baik perusahaan dengan konsumen. Berkat informasi yang akurat, perusahaan dapat mengetahui perilaku konsumen sehingga keputusan-keputusan yang diambil akan dapat meningkatkan kualitas layanan (Griva et al., 2018; Miguéis et al., 2012). Dengan demikian, perusahaan perlu mencari, mengumpulkan, dan menata informasi tentang perilaku konsumen seperti jenis produk yang dibeli, frekuensi (volume) pembelian produk, dan karakteristik konsumen. Informasi mengenai perilaku dan karakteristik konsumen dapat diolah menjadi alat untuk mendesain strategi penjualan atau marketing campaigns (Miguéis et al., 2012). Informasi tentang perilaku pembelian konsumen yang diperoleh itu kemudian diolah dan proses pengolahan data itu disebut dengan customer data mining (CDM).

Customer Data mining adalah proses pencarian informasi melalui pengolahan data yang diperoleh dari aktivitas konsumen untuk mendapatkan informasi tentang perilaku konsumen. Customer Data mining dapat membantu perusahaan untuk melakukan segmentasi konsumen yang didasarkan pada produk yang dibeli (Miguéis et al., 2012), sebagai bahan masukan untuk pengembangan produk dan pengembangan program promosi serta meningkatkan kepuasan konsumen yang akan berdampak pada peningkatan hubungan antara perusahaan dan konsumen (Liao et al., 2011). Perusahaan ritel seperti Tesco, Metro, dan WalMart merupakan contoh perusahaan-perusahaan yang sudah menggunakan customer data mining sebagai dasar pengambilan keputusan (datadriven decision making) dan merasakan manfaat dari customer data mining bagi pemasaran mereka (Griva et al., 2018). Ketika melakukan analisis data pembelian konsumen, Wal-Mart menemukan korelasi yang tinggi antara penjualan produk diaper dan beer pada jam malam. Berdasarkan analisis data ini, manajemen WalMart membuat perubahan program promosi, yaitu merancang kegiatan promosi harga untuk pembelian produk diaper dan beer. Aktivitas promosi harga yang dibuat pada akhirnya dapat membuat Wal-Mart meningkatkan penjualan produk diaper dan beer secara signifikan (https://www.forbes.com/forbes/1998/0406/6107 128a.html\#75553e516260, diakses pada tanggal 16 Juli 2018).

Customer data mining dapat digunakan untuk melakukan segmentasi berdasarkan kategori perilaku konsumen atau profil konsumen (Arunachalam and Kumar, 2018). Segmentasi lain yang dapat dilakukan berdasarkan data konsumen adalah segementasi berdasarkan geografi konsumen, sosial ekonomi, volumen penjualan per hari atau periode waktu tertentu, jenis produk yang dibeli (Miguéis et al., 2012). Metode pengumpulan data untuk proses customer data mining dapat dilakukan melalui pengumpulan data konsumen dari data yang tersimpan pada sistem komputer perusahaan (seperti data konsumen dari mesin kasir) atau secara langsung melalui pembagian kuesioner kepada konsumen di lapangan (Arunachalam and Kumar, 2018; Griva et al., 2018; Liao et al., 2011; Miguéis et al., 2012). Data konsumen akan dianalisis berdasarkan perhitungan nilai frekuensi transaksi (nilai probabilitas) dan nilai perhitungan asosiasi (hubungan) antara satu produk dengan produk lain atau hubungan satu transaksi dengan kondisi/event lain.

Customer data mining diharapkan dapat memberikan banyak manfaat kepada para pedagang di pasar modern dimanapun, khususnya di Bintaro Jaya, Kota Tangerang Selatan, Banten. Pedagang pasar modern di Bintaro Jaya saat ini tidak memiliki data konsumen baik mengenai data yang berisi profil konsumen, perilaku konsumen, pola volume penjualan, dan pola jenis produk terjual sehingga pedangan pasar modern di tempat tersebut tersebut tidak mempunyai pemahaman yang tepat mengenai karakteristik 
dan kebutuhan konsumen. Pedagang pasar modern Bintaro Jaya termasuk jenis pengusaha ritel yang saat ini tengah menghadapi persaingan ketat dengan pedagang pasar modern di wilayah lain.

Berdasarkan diskusi awal dengan para pedagang pasar modern di Bintaro Jaya, diperoleh informasi bahwa konsumen di pasar itu sangat mudah berpindah ke pedagang di pasar modern di wilayah terdekat lain ketika harga barang yang ditawarkan sedikit saja lebih tinggi. Pedagang menjumpai kondisi ketidakstabilan volume penjulan barang sepanjang minggu sehingga pedagang menghadapi masalah turunnya omset penjualan pada hari-hari tertentu. Ketidakstabilan volume penjualan itu kemungkinan lebih disebabkan oleh tidak tepatnya serangkaian keputusan pedagang dan strategi penjualan yang tidak mampu merangsang pembelian ulang konsumen, dan hal itu disinyalir lebih disebabkan oleh rendahnya pemahaman pedagang mengenai masalah perilaku pembelian konsumen. Oleh karena itu, customer data mining diharapkan menjadi dasar pengambilan keputusan (data-driven decision) untuk mendesain strategi penjualan dalam upaya menyelesaikan masalah loyalitas pelanggan dan menjaga tingkat ketidakstabilan omset penjualan pada level yang diinginkan.

\section{METODE PELAKSANAAN}

Customer data mining merupakan suatu program kegiatan pendampingan terstruktur bagi pedagang pasar modern Bintaro Jaya yang fokus pada bidang manajemen pemasaran, khususnya pada pengusaha ritel. Metode pelaksanaan program kegiatan pengabdian masyarakat kepada pedagang pasar modern Bintaro Jaya yang akan dilakukan adalah:

1. Desain kuesioner. Kuesioner merupakan instrumen tulisan yang dibuat untuk menggali informasi dari responden sasaran. Responden sasaran yang dimaksudkan adalah konsumen yang melakukan pembelian produk pedagang di pasar modern Bintaro Jaya. Kuesioner berisi serangkaian pernyataan dan pertanyaan yang akan dibagikan kepada konsumen untuk diisi secara benar dan lengkap sesuai dengan instruksi yang terdapat di dalamnya. Pernyataan dan pertanyaan menyangkut item-item yang mengindikasikan variabel karakteristik diri konsumen, jenis produk yang dibeli, frekuensi (volume) pembelian produk, waktu pembelian, dan alasan pembelian.

2. Pengambilan data. Pengambilan data dilakukan melalui survei lapangan dengan penyebaran instrumen kuesioner yang sudah diuji validitas dan relibilitasnya. Pencarian data dilakukan di pasar modern Bintaro Jaya dan dijalankan dalam periode waktu mulai bulan September sampai dengan Oktober 2018. Agar pencarian data dapat berjalan dengan lancar, penyebaran kuesioner perlu dilakukan secara mandiri oleh pengusul proposal sebagai peneliti. Hal itu ditempuh untuk mengantisipasi kemungkinan adanya pertanyaan dari konsumen yang kurang paham dengan item pernyataan atau pertanyaan kuesioner.

3. Analisis data. Setelah pengumpulan data mencapai jumlah yang ditentukan, data yang diperoleh ditata dan ditabulasi untuk selanjutnya diolah secara mandiri. Secara mandiri berarti bahwa pengusul sebagai peneliti telah menyiapkan keterampilan untuk mengoperasikan alat analisis dengan software yang cocok. Pengolahan data menggunakan teknik analisis yang dipilih sesuai dengan tujuannya. Tahapan ini sekaligus mencakup aktivitas penulisan laporan menyeluruh dari hasil pengolahan dan analisis data yang dilakukan.

4. Sosialisasi hasil customer data mining. Tahapan sosialisasi pada dasarnya merupakan rangkaian kegiatan menyampaikan hasil customer data mining kepada pihak-pihak yang diharapkan menggunakannya. Pihak-pihak yang dimaksudkan di sini adalah para pedagang pasar modern Bintaro Jaya. Meskipun demikian, sosialisasi juga menyasar pihak pengelola pasar modern Bintaro Jaya. Kedua pihak tersebut menjadi agen yang akan menggunakan hasil customer data mining dalam pengambilan keputusan terkait dengan strategi promosi dan penjualan untuk 
meningkatkan daya saing pedagang pasar modern Bintaro Jaya.

5. Pelatihan desain promosi berbasis data Konsumen. Pelatihan merupakan tahapan final dari program kegiatan pengabdian masyarakat bagi pedagang pasar modern Bintaro Jaya. Pelatihan meliputi materi mengenai pembuatan dan penyusunan strategi promosi dan penjualan yang dikembangkan berdasarkan hasil data mengenai konsumen yang diperoleh sebelumnya. Target sasaran pelatihan adalah para pedagang dan pengelola pasar modern
Bintaro Jaya.

Ringkasan metode pelaksanaan kegiatan program pengabdian masyarakat disajikan pada Gambar 2. Kegiatan pengabdian masyarakat ini dilaksanakan di pasar modern Bintaro Jaya beralamat di Jalan Jendral Sudirman - Pusat Kawasan Niaga Bintaro Jaya sektor 7, Pondok Aren Tangerang Selatan. Lokasi pasar modern Bintaro Jaya disajikan pada Gambar 2 serta waktu pelaksanaan program pengabdian masyarakat disajikan pada Tabel 1.

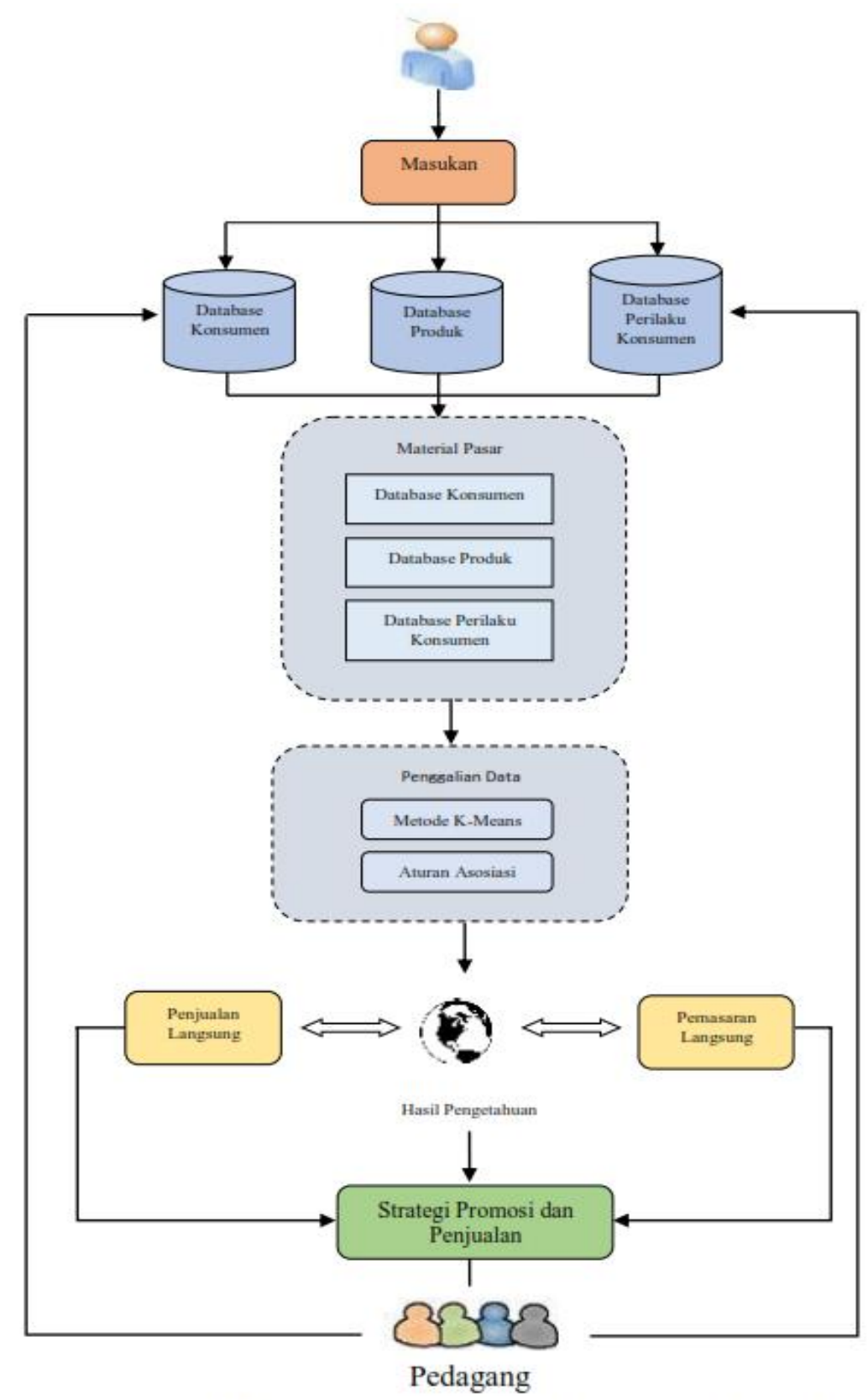

Gambar 1. Metode Pelaksanaan Program Pengabdian Masyarakat 


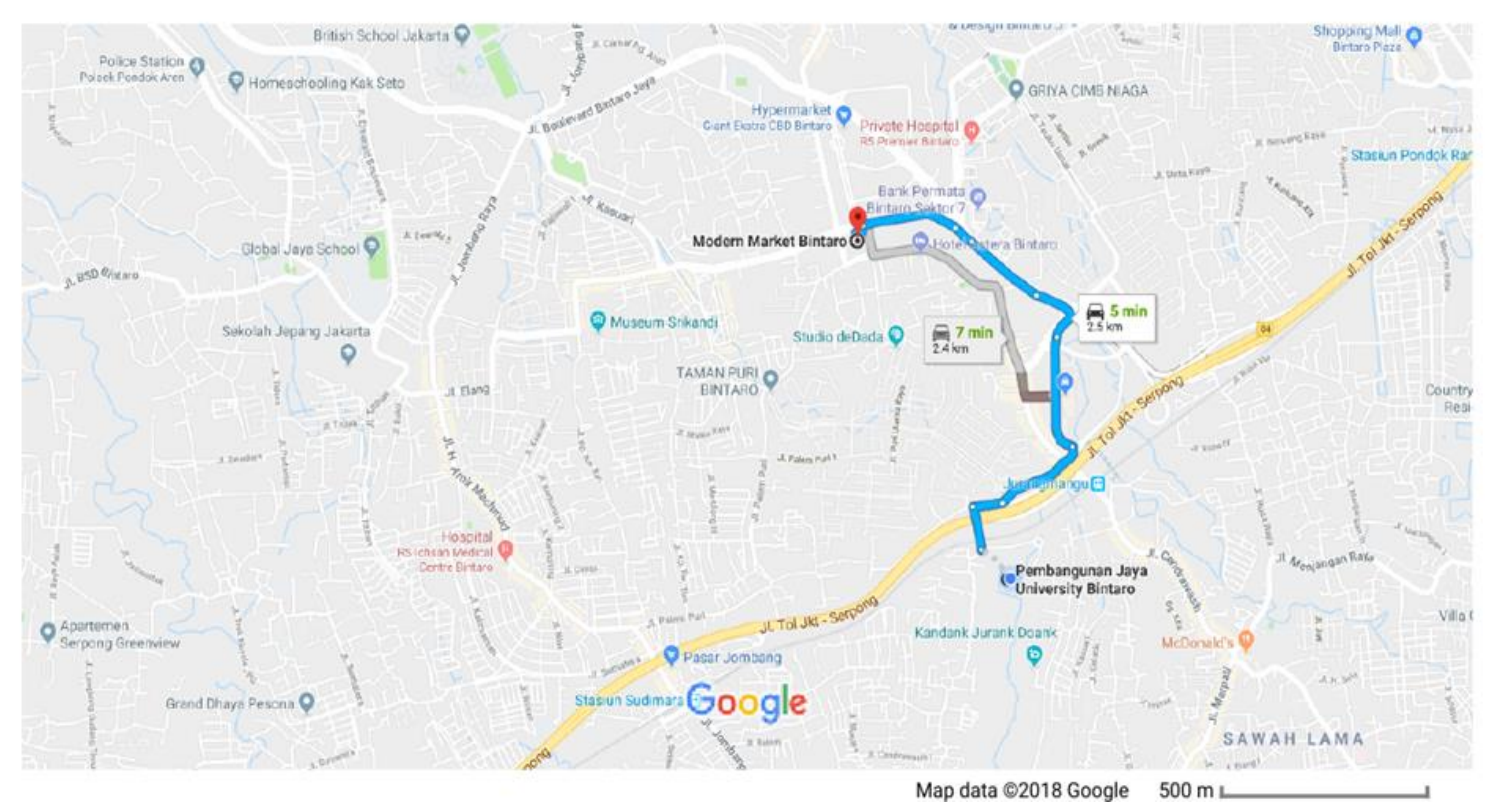

Gambar 2. Lokasi Pengabdian Masyarakat Pasar Modern Bintaro Jaya

Tabel 1 Jadwal Kegiatan

\begin{tabular}{|c|c|c|c|c|c|c|c|c|}
\hline \multirow[t]{2}{*}{ No } & \multirow[b]{2}{*}{ Aktivitas } & \multicolumn{7}{|c|}{ Bulan } \\
\hline & & $\begin{array}{l}\text { Nov } \\
2018\end{array}$ & $\begin{array}{l}\text { Des } \\
2018\end{array}$ & $\begin{array}{l}\text { Jan } \\
2019\end{array}$ & $\begin{array}{l}\text { Feb } \\
2019\end{array}$ & $\begin{array}{l}\text { Mar } \\
2019\end{array}$ & $\begin{array}{l}\text { April } \\
2019\end{array}$ & $\begin{array}{l}\text { Mei } \\
2019\end{array}$ \\
\hline 1 & Diskusi Penyusunan Instrumen Penelitian & & & & & & & \\
\hline 2 & Pengambilan Data Konsumen & & & & & & & \\
\hline 3 & Pengolahan Data & & & & & & & \\
\hline 4 & Interpretasi Data Konsumen & & & & & & & \\
\hline 5 & Penyusunan Strategi Penjualan & & & & & & & \\
\hline 6 & $\begin{array}{l}\text { Sosialisasi Data Konsumen Kepada Pengelola } \\
\text { Pasar Modern dan Pedagang }\end{array}$ & & & & & & & \\
\hline 7 & $\begin{array}{l}\text { Sosialisai Desain Strategi Penjualan yang Diajukan } \\
\text { serta Pelatihan Mendesain Strategi Penjualan } \\
\text { Berbasis Data Konsumen }\end{array}$ & & & & & & & \\
\hline
\end{tabular}

\section{HASIL DAN PEMBAHASAN}

Kuesioner dibagikan kepada 200 pelanggan pasar modern Bintaro Jaya untuk mendapatkan data konsumen. Hanya saja, kuesioner yang diisi lengkap oleh responden sebanyak 180 sehingga respon rate sebesar $90 \%$. Berdasarkan hasil rekapitulasi data dari kuesioner, profil pelanggan pasar modern disajikan pada Tabel 2 .

Tabel 2 Profil Konsumen Pasar Modern Bintaro

\begin{tabular}{clcc}
\hline No & \multicolumn{1}{c}{ Keterangan } & Jumlah & Persen (\%) \\
\hline \multirow{2}{*}{1.} & Jenis Kelamin & & \\
& Laki-laki & 68 & $37,78 \%$ \\
& Perempuan & 112 & $62,22 \%$ \\
\hline & Usia & & \\
& Sampai 20 tahun & 40 & $22,22 \%$ \\
& 21 s/d 25 tahun & 40 & $22,22 \%$ \\
26 s/d 30 tahun & 30 & $16,67 \%$ \\
& 31 s/d 35 tahun & 23 & $12,78 \%$ \\
& 36 s/d 40 tahun & 24 & $13,33 \%$ \\
& 41 s/d 45 tahun & 13 & $7,22 \%$ \\
& Lebih dari 45 tahun & 10 & $5,56 \%$
\end{tabular}




\begin{tabular}{|c|c|c|c|}
\hline No & Keterangan & Jumlah & Persen (\%) \\
\hline 3. & $\begin{array}{l}\text { Status Pernikahan } \\
\text { Menikah } \\
\text { Belum Menikah } \\
\end{array}$ & $\begin{array}{c}100 \\
80 \\
\end{array}$ & $\begin{array}{l}55,56 \% \\
44,44 \%\end{array}$ \\
\hline 4. & $\begin{array}{l}\text { Tempat Tinggal } \\
\text { Bintaro } \\
\text { Luar Bintaro }\end{array}$ & $\begin{array}{c}138 \\
42 \\
\end{array}$ & $\begin{array}{l}76,67 \% \\
23,33 \% \\
\end{array}$ \\
\hline 5. & $\begin{array}{l}\text { Pendidikan } \\
\text { SD/sederajat } \\
\text { SMP } \\
\text { SMU } \\
\text { Diploma } \\
\text { S1 } \\
\text { S2 }\end{array}$ & $\begin{array}{c}11 \\
36 \\
75 \\
9 \\
42 \\
7\end{array}$ & $\begin{array}{c}6,11 \% \\
20 \% \\
41,67 \% \\
5 \% \\
23,33 \% \\
3,89 \%\end{array}$ \\
\hline 6. & $\begin{array}{l}\text { Pendapatan } \\
2,5 \text { juta s/d } 5 \text { juta } \\
5,1 \text { juta s/d } 7,5 \text { juta } \\
7,6 \text { juta s/d } 10 \text { juta } \\
10,1 \text { juta } \mathrm{s} / \mathrm{d} 12,5 \text { juta } \\
12,6 \text { juta s/d } 15 \text { juta } \\
15,1 \text { juta s/d } 17,5 \text { juta } \\
17,6 \text { juta s/d } 20 \text { juta } \\
20,1 \text { juta } \mathrm{s} / \mathrm{d} 22,5 \text { juta } \\
\text { Lebih dari } 22,5 \text { juta }\end{array}$ & $\begin{array}{c}104 \\
30 \\
11 \\
9 \\
3 \\
8 \\
0 \\
5 \\
10\end{array}$ & $\begin{array}{c}57,78 \% \\
16,67 \% \\
16,11 \% \\
5 \% \\
1,67 \% \\
4,44 \% \\
0 \\
2,78 \% \\
5,56 \%\end{array}$ \\
\hline
\end{tabular}

Sumber: Penulis (2018)

Berdasarkan hasil survei, ditemukan bahwa mayoritas konsumen pasar modern Bintaro Jaya adalah perempuan $(62,22 \%)$, berada pada rentang usia 20 tahun sampai dengan 25 tahun (80\%), konsumen yang sudah menikah $(55,56 \%)$, mayoritas bertempat tinggal di Bintaro Jaya (76,67\%), mayoritas memiliki latar belakang pendidikan SMU $(41,67 \%)$ dan sarjana strata satu $(23,33 \%)$, serta memiliki penghasilan 2,5 juta sampai 10 juta per bulan.

Rekapitulasi pola frekuensi pembelian produk dalam seminggu serta pola pembelian beberapa jenis produk yang berbeda tetapi dilakuan bersamaan adalah disajikan pada Tabel 3. Frekuensi pembelian yang paling banyak dilakukan oleh konsumen pasar modern Bintaro
Jaya adalah barang pada kategori kebutuhan pangan yaitu beras, gula, tepung terigu, minyak goreng, kedelai, bawang merah, bawang putih, cabe, daging, ikan, telur, sayur-sayuran, dan jajanan tradisional. Konsumen yang membeli beras satu kali seminggu sebanyak 80 responden $(44,44 \%)$. Hasil survei menunjukkan bahwa penjualan beras di pasar modern Bintaro Jaya memiliki frekuensi penjualan yang tinggi karena 33 responden $(18,33 \%)$ melakukan pembelian beras 4 kali dalam seminggi dan 30 responden $(16,67 \%)$ melakukan pembelian beras 6 kali dalam seminggu.

Tabel 3 Pola Perilaku Pembelian Konsumen Pasar Modern Bintaro Jaya

\begin{tabular}{cccc}
\hline No. & Nama Produk & $\begin{array}{c}\text { Frekuesi Pembelian } \\
\text { dalam Seminggu }\end{array}$ & $\begin{array}{c}\text { Jumlah Konsumen } \\
\text { (orang) }\end{array}$ \\
\hline & & $1 \mathrm{kali}$ & 80 \\
& & $2 \mathrm{kali}$ & 17 \\
1. & \multirow{2}{*}{ Beras } & $3 \mathrm{kali}$ & 6 \\
& & $4 \mathrm{kali}$ & 33 \\
& & $5 \mathrm{kali}$ & 14 \\
& & $6 \mathrm{kali}$ & 30 \\
\hline \multirow{2}{*}{2.} & Gula & $1 \mathrm{kali}$ & 52 \\
& & $2 \mathrm{kali}$ & 56 \\
\hline
\end{tabular}




\begin{tabular}{|c|c|c|c|}
\hline No. & Nama Produk & $\begin{array}{c}\text { Frekuesi Pembelian } \\
\text { dalam Seminggu }\end{array}$ & $\begin{array}{c}\text { Jumlah Konsumen } \\
\text { (orang) }\end{array}$ \\
\hline & & 3 kali & 13 \\
\hline & & 4 kali & 8 \\
\hline & & 5 kali & 15 \\
\hline & & 6 kali & 36 \\
\hline \multirow{6}{*}{3.} & \multirow{6}{*}{ Tepung Terigu } & $1 \mathrm{kali}$ & 85 \\
\hline & & 2 kali & 28 \\
\hline & & 3 kali & 22 \\
\hline & & 4 kali & 11 \\
\hline & & 5 kali & 15 \\
\hline & & 6 kali & 19 \\
\hline \multirow{6}{*}{4.} & \multirow{6}{*}{ Minyak Goreng } & 1 kali & 49 \\
\hline & & 2 kali & 84 \\
\hline & & 3 kali & 15 \\
\hline & & 4 kali & 9 \\
\hline & & 5 kali & 10 \\
\hline & & 6 kali & 13 \\
\hline \multirow{6}{*}{5.} & \multirow{6}{*}{ Kedelai } & 1 kali & 77 \\
\hline & & 2 kali & 34 \\
\hline & & 3 kali & 36 \\
\hline & & 4 kali & 11 \\
\hline & & 5 kali & 10 \\
\hline & & 6 kali & 12 \\
\hline \multirow{6}{*}{6.} & \multirow{6}{*}{ Bawang Merah } & 1 kali & 56 \\
\hline & & 2 kali & 29 \\
\hline & & 3 kali & 73 \\
\hline & & 4 kali & 10 \\
\hline & & 5 kali & 8 \\
\hline & & 6 kali & 4 \\
\hline \multirow{6}{*}{7.} & \multirow{6}{*}{ Bawang Putih } & 1 kali & 54 \\
\hline & & 2 kali & 85 \\
\hline & & 3 kali & 17 \\
\hline & & 4 kali & 12 \\
\hline & & 5 kali & 9 \\
\hline & & 6 kali & 3 \\
\hline \multirow{6}{*}{8.} & \multirow{6}{*}{ Cabe } & 1 kali & 51 \\
\hline & & 2 kali & 87 \\
\hline & & 3 kali & 15 \\
\hline & & 4 kali & 13 \\
\hline & & 5 kali & 8 \\
\hline & & 6 kali & 6 \\
\hline \multirow{6}{*}{9.} & \multirow{6}{*}{ Daging } & 1 kali & 65 \\
\hline & & 2 kali & 14 \\
\hline & & 3 kali & 24 \\
\hline & & 4 kali & 25 \\
\hline & & 5 kali & 14 \\
\hline & & 6 kali & 38 \\
\hline \multirow{6}{*}{10.} & \multirow{6}{*}{ Ikan } & 1 kali & 65 \\
\hline & & 2 kali & 25 \\
\hline & & 3 kali & 23 \\
\hline & & 4 kali & 14 \\
\hline & & 5 kali & 43 \\
\hline & & 6 kali & 10 \\
\hline 11. & Telur & 1 kali & 50 \\
\hline
\end{tabular}




\begin{tabular}{|c|c|c|c|}
\hline No. & Nama Produk & $\begin{array}{c}\text { Frekuesi Pembelian } \\
\text { dalam Seminggu }\end{array}$ & $\begin{array}{c}\text { Jumlah Konsumen } \\
\text { (orang) }\end{array}$ \\
\hline & & 2 kali & 39 \\
\hline & & 3 kali & 37 \\
\hline & & 4 kali & 15 \\
\hline & & 5 kali & 18 \\
\hline & & 6 kali & 21 \\
\hline \multirow{6}{*}{12.} & \multirow{6}{*}{ Sayur-sayuran } & $1 \mathrm{kali}$ & 46 \\
\hline & & 2 kali & 42 \\
\hline & & 3 kali & 23 \\
\hline & & 4 kali & 33 \\
\hline & & 5 kali & 20 \\
\hline & & 6 kali & 16 \\
\hline \multirow{6}{*}{13.} & \multirow{6}{*}{ Jajanan Tradisional } & 1 kali & 38 \\
\hline & & 2 kali & 37 \\
\hline & & 3 kali & 16 \\
\hline & & 4 kali & 25 \\
\hline & & 5 kali & 27 \\
\hline & & 6 kali & 37 \\
\hline \multirow{6}{*}{14.} & \multirow{6}{*}{ Kopi/Teh } & 1 kali & 17 \\
\hline & & 2 kali & 67 \\
\hline & & 3 kali & 21 \\
\hline & & 4 kali & 21 \\
\hline & & 5 kali & 33 \\
\hline & & 6 kali & 21 \\
\hline \multirow{6}{*}{15.} & \multirow{6}{*}{ Pakaian } & 1 kali & 31 \\
\hline & & 2 kali & 42 \\
\hline & & 3 kali & 42 \\
\hline & & 4 kali & 49 \\
\hline & & 5 kali & 11 \\
\hline & & 6 kali & 0 \\
\hline \multirow{4}{*}{16.} & \multirow{4}{*}{ Sepatu } & 1 kali & 62 \\
\hline & & 2 kali & 51 \\
\hline & & 3 kali & 21 \\
\hline & & 4 kali & 31 \\
\hline \multirow{6}{*}{17.} & \multirow{6}{*}{ Sandal } & $1 \mathrm{kali}$ & 91 \\
\hline & & 2 kali & 40 \\
\hline & & 3 kali & 41 \\
\hline & & 4 kali & 1 \\
\hline & & 5 kali & 7 \\
\hline & & 6 kali & 0 \\
\hline \multirow{6}{*}{18.} & \multirow{6}{*}{ Tissue } & 1 kali & 157 \\
\hline & & 2 kali & 7 \\
\hline & & 3 kali & 3 \\
\hline & & 4 kali & 1 \\
\hline & & 5 kali & 11 \\
\hline & & 6 kali & 0 \\
\hline
\end{tabular}

Sumber: Penulis (2018)

Pembelian kebutuhan pangan lainnya yang memiliki frekuensi pembelian tinggi adalah:

1. Gula $\rightarrow 56$ responden $(31,11 \%)$ melakukan pembelian gula di pasar modern Bintaro Jaya sebanyak 2 kali dalam seminggu; 52 responden $(28,89 \%)$ melakukan pembelian gula sebanyak 1 kali dalam seminggu; 36 responden $(20 \%)$ melakukan pembelian gula sebanyak 6 kali dalam seminggu; 
2. Tepung terigu $\rightarrow 86$ responden $(47,78 \%)$ melakukan pembelian 1 kali dalam seminggu; 28 responden $(15,56 \%)$ melakukan pembelian 2 kali dalam seminggu; 22 responden (12,22\%) melakukan pembelian 3 kali seminggu;

3. Minyak goring $\rightarrow 84$ respoden $(46,67 \%)$ melakukan pembelian 2 kali dalam seminggu; 49 responde $(27,22 \%)$ melakukan pembelian 1 kali dalam seminggu; 15 responden $(8,33 \%)$ melakukan pembelian 3 kali dalam seminggu;

4. Kedelai $\rightarrow 77$ responden $(42,78 \%)$ melakukan pembelian 1 kali dalam seminggu; 36 responden (20\%) melakukan pembelian 3 kali dalam seminggu; 34 responden $(18,89 \%)$ melakukan pembelian 2 kali dalam seminggu;

5. Bawang merah $\rightarrow 73$ responden $(40,56 \%)$ melakukan pembelian 3 kali dalam seminggu; 56 responden $(31,11 \%)$ melakukan pembelian 1 kali dalam seminggu; 29 responden $(16,11 \%)$ melakukan pembelian 2 kali dalam seminggu;

6. Bawang putih $\rightarrow 85$ responden $(47,22 \%)$ melakukan pembelian 2 kali dalam seminggu; 54 responden (30\%) melakukan pembelian 1 kali dalam seminggu; 17 responden $(9,44 \%)$ melakukan pembelian 3 kali dalam seminggu;

7. Cabe $\rightarrow 87$ responden $(48,33 \%)$ melakukan pembelian sebanyak 2 kali dalam seminggu; 51 responden $(28,33 \%)$ melakukan pembelian 1 kali dalam seminggu; 15 responden $(8,33 \%)$ melakukan pembelian 3 kali dalam seminggu;

8. Daging $\rightarrow 65$ responden $(36,11 \%)$ melakukan pembelian 1 kali dalam seminggu; 38 responden $(21,11 \%)$ melakukan pembelian 6 kali dalam seminggu; 25 responden $(13,88 \%)$ melakukan pembelian 4 kali dalam seminggu;

9. Ikan $\rightarrow 65$ responden $(36,11 \%)$ melakukan pembelian 1 kali dalam seminggu; 43 responden $(23,89 \%)$ melakukan pembelian 5 kali dalam seminggu; 25 responden
$(13,88 \%)$ melakukan pembelian 2 kali dalam seminggu;

10.Telur $\rightarrow 50$ responden $(27,78 \%)$ melakukan pembelian 1 kali dalam seminggu; 39 responden $(21,67 \%)$ melakukan pembelian 2 kali dalam seminggu; 37 responden $(20,56 \%)$ melakukan pembelian 3 kali dalam seminggu;

11.Sayur-sayuran $\rightarrow 46$ responden $(25,56 \%)$ melakukan pembelian 1 kali dalam seminggu; 42 responden $(23,33 \%)$ melakukan pembelian 2 kali dalam seminggu; 33 responden (18,33\%) melakukan pembelian 4 kali dalam seminggu;

12.Jajanan tradisional $\rightarrow 38$ responden $(21,11 \%)$ melakukan pembelian 1 kali dalam seminggu; 37 responden $(20,55 \%)$ melakukan pembelian 6 kali dalam seminggu serta 37 responden $(20,55 \%)$ melakukan pembelian 2 kali dalam seminggu;

13.Kopi/the $\rightarrow 67$ responden $\quad(37,22 \%)$ melakukan pembelian 2 kali dalam seminggu; 33 responden (18,33\%) melakukan pembelian 5 kali dalam seminggu; 21 responden $(11,67 \%)$ melakukan pembelian 3, 4, dan 6 kali dalam seminggu

Pedagang pasar modern Bintaro Jaya yang menjual produk kebutuhan pangan memiliki potensi besar untuk meningkatkan dan mempertahankan volume penjualan karena hasil survei menunjukkan bahwa konsumen sering melakukan pembelian produk kategori pangan. Bahkan untuk produk-produk tertentu, jumlah konsumen yang melakukan pembelian produk tersebut setiap hari masuk dalam kategori urutan frekunsi pembelian peringkat tiga tertinggi.

Pembelian produk pada kategori lain yang memiliki frekuensi pembelian tinggi adalah: (1) tissue yaitu 157 atau 87,22\% responden melakukan pembelian tissue 1 kali dalam seminggu; (2) sandal yaitu 91 responden atau $50,56 \%$ melakukan pembelian sandal 1 kali seminggu; (3) sepatu yaitu 62 responden atau $34,44 \%$ melakukan pembelian 1 kali seminggu dan 51 responden atau 28,33\% melakukan 
pembelian 2 kali dalam seminggu. Berdasarkan data hasil survei ini, maka potensi meningkatkan volum penjualan bagi pedagang pasar modern Bintaro Jaya dengan melihat frekuensi pembelian dan jumlah responden yang melakukan pembelian maka penjualan tissue, sandal, sepatu memiliki peluang tinggi. Hasil rekapitulasi jawaban dari hasil kuesioner yang kembali menunjukkan bahwa konsumen hampir tidak pernah melakukan pembelian produk pada kategori sandang seperti perlengkapan rumah tangga yang dibeli dan hanya 1 sampai 5 responden (dari 180 responden) yang menjawab pernah melakukan pembelian sandang selain tissue, sandal, dan sepatu. Hal ini menunjukkan bahwa konsumen pasar modern Bintaro Jaya tidak menjadikan pasar modern Bintaro Jaya sebagai tempat pembelian sandang.

Customer data mining yang dapat diperoleh dari hasil rekapitulasi survei adalah pola pembelian produk-produk yang dilakukan bersamaan. Informasi pola pembelian produk/barang yang dibeli secara bersamaan disajikan pada Tabel 4. Informasi ini akan dapat digunakan untuk mendesain strategi peningkatan penjualan volume melalui bundling product. Kombinasi bundling product yang dapat dilakukan adalah: (1) bawang putih, bawang merah, cabe, sayur; (2) gula, tepung, dan minyak; (3) daging, telur, ikan; (4) beras, gula, tepung, minyak. Bundling product ini jika dilihat dari pola pembelian maka perilaku konsumen melakukan pembelian penggabungan variasi produk atas dasar: (1) keterkaitan fungsi produk tersebut; (2) kemudahan dalam membawa produk ketika konsumen melakukan pembelian. Sehingga untuk meningkatkan volume penjualan jika hendak menggunakan budling product maka pedagang pasar modern dapat menggunakan pola ini. Informasi lain yang diperoleh dari customer data mining adalah:

a. 140 responden $(77,78 \%)$ menjawab mereka membeli barang-barang kebutuhan rumah tangga sehari-hari;

b. 103 responden (57\%) menghabiskan waktu selama 1 jam di pasar modern dan 61 respondn (39\%) menghabiskan waktu 2 Jam. Sehingga mayoritas reponden paling lama menghabiskan waktu selama 2 jam di pasar modern Bintaro Jaya;

c. 110 responden $(61,11 \%)$ menyatakan bahwa sarana (seperti toilet dan informasi) di pasar modern Bintaro Jaya dapat mempengaruhi niat mereka untuk datang berbelanja;

d. 150 responden $(83,33 \%)$ menyatakan bahwa pasar modern Bintaro Jaya menyediaka menu makanan lokal Tangerang yang menjadi salah satu daya tarik bagi konsumen datang berbelanja;

e. 100 responden $(55,56 \%)$ menyatakan bahwa sarana tempat duduk umum di pasar modern Bintaro tidak memadai sehingga mengurangi kenyamanan pengunjung;

f. 100 responden $(55,56 \%)$ menyatakan pasar modern Bintaro menyediakan fasilitas t-cash/e-money) sebagai sarana pembayaran dan sarana ini memudahkan transaksi selama berbelanja;

g. 140 responden $(77,78 \%)$ menyatakan bahwa pedagang pasar modern Bintaro tidak memberikan apresiasi kepada pelanggan sebagai penanda loyalitas mereka berbelanja;

h. 140 responen $(77,78 \%)$ menyatakan bahwa lahan parkir kendaraan kurang memadai di pasar modern Bintaro;

i. 120 responden $(66,67 \%)$ menyatakan bahwa kondisi pasar modern kurang nyaman dan merasakan kegaduhan yang berlebihan;

j. 152 responden $(84,44 \%)$ menyatakan bahwa pasar modern Bintaro tidak menyediakan infomasi yang membantu pelanggan dalam berbelanja seperi informasi yang disajikan melalui televisi di kawasan pasar

Jawaban pelanggan pasar modern menunjukkan bahwa tujuan Konsumen datang ke pasar modern adalah untuk membeli produk kebutuhan seharihari. Hasil ini konsisten dengan frekuensi yang tinggi untuk pembelian kebutuhan pangan. Hanya saja, hasil survei menunjukkan bahwa fasilitas yang disediakan oleh pengelola pasar modern dipersepsikan kurang baik oleh pelanggan hal ini yang menyebabkan pelanggan pasar modern 
hanya bersedia menghabiskan waktu paling lama 2 jam di pasar. Pengelola pasar dapat memanfaatkan keberagaman jenis makanan lokal yang dijual oleh pedagang pasar untuk meningkatkan durasi kunjungan karena keberagaman menu makanan dipersepsikan baik oleh mayoritas responden dan faktor ini menjadi alasan pengunjung datang ke pasar modern.

Tabel 4 Pola Pembelian Jenis Produk Yang Dilakukan Bersamaan

\begin{tabular}{|c|c|c|c|c|c|c|c|c|c|c|c|c|}
\hline Pola & Beras & Cabe & Sayur & $\begin{array}{c}\text { Bawang } \\
\text { Merah } \\
\end{array}$ & $\begin{array}{c}\text { Bawang } \\
\text { Putih } \\
\end{array}$ & $\begin{array}{c}\text { Jajan } \\
\text { Tradisional } \\
\end{array}$ & Gula & Tepung & Minyak & Daging & Telur & Ikan \\
\hline 1 & $\mathbf{x}$ & $\mathbf{X}$ & & & & & & & & & & \\
\hline 2 & $\mathbf{x}$ & & $\mathbf{X}$ & & & & & & & & & \\
\hline 3 & $\mathbf{x}$ & & $\mathbf{x}$ & $\mathbf{x}$ & $\mathbf{x}$ & $\mathbf{X}$ & & & & & & \\
\hline 4 & $\mathbf{x}$ & & & & & & $\mathbf{x}$ & $\mathbf{x}$ & $\mathbf{X}$ & $\mathbf{X}$ & $\mathbf{x}$ & \\
\hline 5 & $\mathbf{x}$ & & & & & & & & $\mathbf{x}$ & & & \\
\hline 6 & $\mathbf{x}$ & & & $\mathbf{x}$ & $\mathbf{x}$ & & $\mathbf{x}$ & $\mathbf{x}$ & $\mathbf{x}$ & $\mathbf{X}$ & $\mathbf{x}$ & $\mathbf{X}$ \\
\hline 7 & $\mathbf{x}$ & $\mathbf{X}$ & & & & & & & & & & \\
\hline 8 & $\mathbf{x}$ & & $\mathbf{x}$ & $\mathbf{x}$ & & & & & & & & \\
\hline 9 & $\mathbf{X}$ & $\mathbf{X}$ & & & & & & & & & & \\
\hline 10 & $\mathrm{X}$ & & $\mathbf{X}$ & & & & & & & & & \\
\hline 11 & $\mathbf{x}$ & & $\mathbf{X}$ & & & & & & & & & \\
\hline 12 & $\mathbf{x}$ & & & & & & $\mathbf{x}$ & $\mathbf{x}$ & $\mathbf{X}$ & & & \\
\hline 13 & $\mathbf{x}$ & & & $\mathbf{x}$ & & & $\mathbf{x}$ & $\mathbf{x}$ & & & & \\
\hline 14 & $\mathbf{x}$ & & & & & & $\mathbf{x}$ & $\mathbf{x}$ & $\mathbf{x}$ & & $\mathbf{x}$ & \\
\hline 15 & $\mathbf{x}$ & & $\mathbf{X}$ & $\mathbf{x}$ & $\mathbf{x}$ & & $\mathbf{x}$ & $\mathbf{x}$ & $\mathbf{x}$ & & $\mathbf{x}$ & \\
\hline 16 & $\mathbf{x}$ & & & & & $\mathbf{x}$ & $\mathbf{x}$ & & & & & \\
\hline 17 & & $\mathbf{x}$ & $\mathbf{x}$ & $\mathbf{x}$ & $\mathbf{x}$ & & & & & $\mathbf{x}$ & $\mathbf{x}$ & $\mathbf{X}$ \\
\hline 18 & & $\mathbf{X}$ & & $\mathbf{X}$ & $\mathbf{X}$ & & & & & & & \\
\hline 19 & & & & $\mathbf{x}$ & $\mathbf{x}$ & & & & & & & \\
\hline 20 & & $\mathbf{x}$ & $\mathbf{x}$ & $\mathbf{x}$ & $\mathbf{x}$ & & & & & $\mathbf{x}$ & & \\
\hline 21 & & $\mathbf{x}$ & $\mathbf{x}$ & $\mathbf{x}$ & $\mathbf{x}$ & & & & & & & \\
\hline 22 & & & $\mathbf{x}$ & $\mathbf{x}$ & $\mathbf{x}$ & & & & & & & \\
\hline 23 & & $\mathbf{x}$ & & $\mathbf{x}$ & $\mathbf{x}$ & & & & & & & \\
\hline 24 & & & $\mathbf{x}$ & $\mathbf{x}$ & $\mathbf{x}$ & & & & & & & \\
\hline 25 & - & & $\mathbf{x}$ & $\mathbf{x}$ & $\mathbf{x}$ & $\mathbf{x}$ & & & & & & \\
\hline
\end{tabular}

\section{SIMPULAN DAN SARAN}

Berdasarkan customer data mining yang dilakukan maka alasan konsumen datang ke pasar modern Bintaro Jaya adalah pembelian produk kebutuhan sehari-hari yang habis pakai Mayoritas konsumen pasar modern Bintaro Jaya adalah perempuan yang berada pada rentang usia 20 tahun sampai dengan 25 tahun, konsumen yang sudah menikah, dan bertempat tinggal di Bintaro Jaya. Latar belakang pendidikan SMU dan sarjana strata satu, serta memiliki penghasilan 2,5 juta sampai 10 juta per bulan.

Strategi meningkatkan volume penjualan yang dapat dilakukan oleh pedagang pasar modern dapat menggunakan pola perilaku pembelian Konsumen, yaitu pola pembelian barang secara bersamaan. Bundling product yang dapat dilakukan adalah: (1) bawang putih, bawang merah, cabe, sayur; (2) gula, tepung, dan minyak; (3) daging, telur, ikan; (4) beras, gula, tepung, minyak. Bundling product ini jika dilihat dari pola pembelian maka perilaku konsumen melakukan pembelian penggabungan variasi produk atas dasar: (1) keterkaitan fungsi produk tersebut; (2) kemudahan dalam membawa produk ketika konsumen melakukan pembelian

\section{UCAPAN TERIMAKASIH}

Ucapan terimakasih disampaikan kepada 1) Pegelola pasar modern Bintaro Jaya, 2) Kepada pedagang pasar modern Bintaro Jaya, 3) Kepada Universitas Pembangunan Jaya yang telah mendanai program pengabdian masyarakat ini.

\section{DAFTAR PUSTAKA}

Arunachalam, D., Kumar, N. (2018). Benefitbased consumer segmentation and performance evaluation of clustering approaches: An evidence of data-driven 
decision-making. Expert Syst. Appl. https://doi.org/10.1016/j.eswa.2018.03.00 7

Griva, A., Bardaki, C., Pramatari, K. Papakiriakopoulos, D. (2018). Retail business analytics: Customer visit segmentation using market basket data. Expert Syst. Appl. 100, 1-16. https://doi.org/10.1016/j.eswa.2018.01.02 9

Liao, S., Chen, Y., Hsieh, H. (2011). Mining customer knowledge for direct selling and marketing. Expert Syst. Appl. 38, 6059-
6069.

https://doi.org/10.1016/j.eswa.2010.11.00 7

Miguéis, V.L., Camanho, A.S., Falcão e Cunha, J. (2012). Customer data mining for lifestyle segmentation. Expert Syst. Appl. 39 , 9359-9366. https://doi.org/10.1016/j.eswa.2012.02.1 33 